\title{
Evolution of the sectoral system of innovation of India's aeronautical industry
}

\author{
Sunil Mani \\ Centre for Development Studies, \\ Prasanth Nagar, Ulloor, \\ Trivandrum 695011, Kerala, India \\ E-mail: Mani@cds.ac.in
}

\begin{abstract}
India is one among the few developing countries that have sought to establish an aerospace industry. The industry has two components, namely aeronautical and astronautical. Historically speaking, India has focused much more on the astronautical part of the industry. However, in the present paper, the emphasis is on understanding the aeronautical part of the aerospace industry. We first map out the sectoral system of innovation of this industry, which is actually located as a cluster in the south Indian city of Bangalore. The paper identifies the three building blocks of the sectoral system: lead actors, knowledge or technology domain, and the demand. Changes in each of these blocks over time are discussed. The study concluded with a comparison of the performance of the sector in terms of exports and competitiveness and also delves on the policy instruments that are required for placing the industry on a sure flight path.
\end{abstract}

Keywords: India; sectoral system of innovation; aerospace industry; aeronautical; astronautic; commercial aircraft industry; offset policy.

Reference to this paper should be made as follows: Mani, S. (2013) 'Evolution of the sectoral system of innovation of India's aeronautical industry', Int. J. Technology and Globalisation, Vol. 7, Nos. 1/2, pp.92-117.

Biographical notes: Sunil Mani is Professor and Planning Commission Chair at Centre for Development Studies, Trivandrum, Kerala, India. He is also a member of the Advisory Steering Committee of the Centre for Science, Technology and Innovation Indicators, Human Sciences Research Council, Republic of South Africa and a Visiting Faculty at the Globelics Academy and at the Indian Institute of Management-Calcutta, India. His areas of research include measurement of innovation, innovation policy instruments and innovation capability in high technology industries such as aerospace and telecommunications industries.

\section{Introduction}

India is one among the few developing countries, which have attempted to create a domestic sectoral system of innovation in a truly high tech sector such as the aerospace industry. The country is currently having one of the fastest growing aerospace sectors in the world: exports of aerospace products from India have grown at a rate of $114 \%$ per annum (in nominal terms) during the period 1996 through 2009. Although the sectoral 
system of innovation of the industry is almost five decades old, for much of that period both manufacturing and innovative efforts of the sector was geared solely towards the defence sector, but this orientation of almost entire defence and governmental hold of the sector started diminishing with the opening up of the sector to private sector actors in 2001. So the evolution of the SSI neatly fits itself into two phases: phase 1 is period, 1959-2001 when both the research and manufacturing were entirely geared towards the defence sector and phase 2 is period since 2001 when the government opened up the sector to private sector participation. In fact, this radical shift in policy appears to have made the sector very dynamic in the sense that it has considerably enhanced the breadth and depth of its activities in both research and manufacturing in both the aeronautical and astronautic components of the aerospace industry. Historically speaking Indian public policy has been disproportionately directed towards the astronautic part than the aeronautical so much to say that in terms of public expenditure intensity on space related activities (defined as expenditure on space as percent of GDP), India is second only to the USA, but ahead of many other OCED and BRIC countries (see Figure 1).

Figure 1 Public space budgets for OECD and BRIC countries as a percent of their GDP, 2005 (see online version for colours)

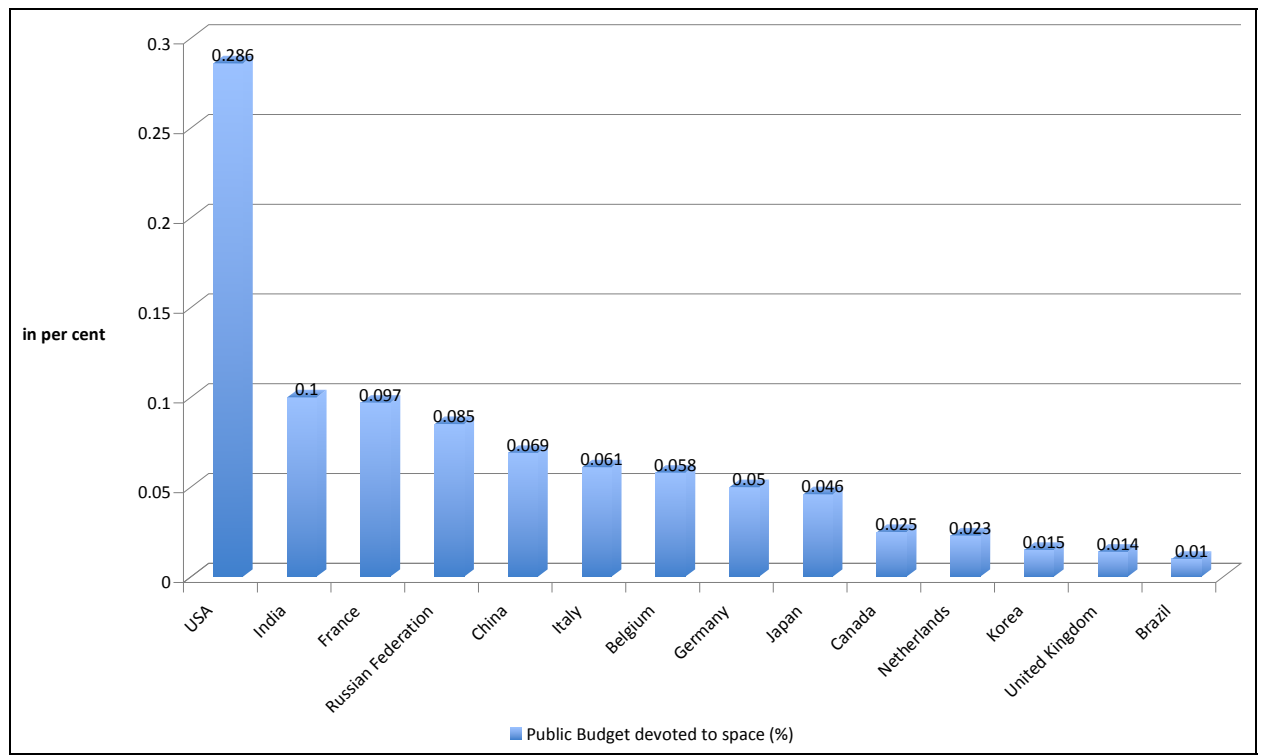

Notes: BRIC countries are Brazil, Russia, India and China. Chinese data based on unofficial estimates.

Source: Adapted from $\operatorname{OECD}(2007$, p.35)

Aerospace industry across the world is structured in the form of clusters. This is because at the centre of the cluster is a large aircraft manufacturer with a whole host of component manufacturers around it. In India, the southern city of Bangalore has emerged as one of the leading aerospace clusters in the country. This is essentially due to the existence of four major actors in the SSI of the sector, namely Hindustan Aeronautics Ltd (HAL) (leading manufacturer of aerospace products). The National Aerospace Laboratory (NAL) (leading research facility on aerospace domain under the CSIR network of laboratories across the country), the Indian Space Research Organization 
(ISRO) (leading researcher and consumer of especially astronautics products from the country), and the Indian Institute of Science (leading centre for training of aerospace engineers).

The main research question that is analysed in the paper is the evolution of the sectoral system of innovation of the aerospace sector in India over the years. Our argument is that, over time, the sector has evolved from one that is dominated by defence projects to one that is increasingly becoming dominated by civilian aircraft projects. This evolution, to a large extent, has been facilitated by a significant increase in the demand for domestic air travel coupled with the introduction of explicit instruments by the state to encourage domestic manufacture of aircrafts and parts. In this way, the state continues to be an important actor in the SSI of this sector.

The aerospace sector consists of both aeronautical and astronautics. However, in the present study, we are confining ourselves to only the aeronautical part of the industry.

The paper is structured into six sections. Section 2 outlines the analytical framework underlying the study and also has a brief engagement with the literature on the aerospace industry in India. Section 3 maps out the sectoral system of innovation in terms of its various constituents and measures its performance in terms of a number of indicators. Section 4 analyses the contours of the knowledge domain in terms of various civil aircraft $R \& D$ projects undertaken or being undertaken in the country. Section 5 discusses the recent changes in public policies attempting to create a domestic aircraft manufacturing country. Finally, Section 6 sums up the findings and draws the implications of the study.

\section{Framework for analysis}

In the case of India's aeronautical industry most of the institutions constituting its sectoral system are located in and around the city of Bangalore. In this way, there is a fair amount of overlapping between the SSI and the Bangalore aeronautical cluster. So in our study I use the terms, sectoral system of innovation of India's aeronautical industry and the Bangalore aerospace cluster interchangeably. Consequently, the framework that we employ is an eclectic one by combining elements of the literature on clusters and the one on sectoral systems of innovation as advanced by Malerba (2004). The eclectic SSI framework identifies three crucial elements of the sector, namely:

- $\quad$ lead actors in the sector

- knowledge domain and development

- demand.

As far as India's aerospace industry is concerned, significant changes have taken place in all the three building blocks. For instance, during phase 1 the knowledge and technology domain depended to a great extent or almost in its entirety on domestic sources. The actors and institutions were led by one public laboratory, one public sector research organisation which did both research and manufacturing and one leading public sector enterprise in the manufacturing sector and demand was almost entirely driven by public technology procurement. But during phase 2 there has been a dramatic change in all the three building blocks with the knowledge domain now composed of both domestic and foreign sources, there has been considerable increase in the number and types of actors and institutions and the demand has shifted from domestic public sector to foreign private 
and public sector enterprises. Fast growth in domestic civil aviation, development in manufacturing (especially in the private sector), and emergence of India as an aerospace technology-sourcing centre.

\subsection{Engagement with the literature}

Systematic academic literature on India's aerospace industry is scanty and focuses almost exclusively on the astronautic part. Three sets of issues have come up for inquiry and analysis in this literature. The first one deals with overall assessment of past and future public policies on space programmes (Rajan, 1988; Kasturirangan, 2004; Murthi et al., 2009). The second one is a more detailed study on the evolution of the space sector from one being more science oriented to one that is more commercial-oriented. The studies in this set also deal with the way India has acquired technological capability in this area (Baskaran, 2005; Sankar, 2007). The last one deals with one particular kind of space technology, namely remote sensing, in which India has managed to have considerable technological capability. The only study in this set (Satheesh, 2009) deals with the extent of diffusion of this technology and the factors that have contributed to its diffusion. To the best of our knowledge no studies exist on the aeronautical part of the sector. The present study thus seeks to fill in this gap by focusing on both the sectors and especially on the aeronautical part of the industry.

\section{Demystifying the aeronautical sectoral system of innovation}

The city of Bangalore, capital of the southern state of Karnataka, has shot into international fame as the centre for India's information technology industry and also as an innovation hub. Besides, it has a very high density of national level research institutes focusing on a range of technology disciplines, same basic and some applied as well. It has also a very high density of undergraduate and graduate institutions in science and engineering and some of them like the Indian Institute of Science are of international repute. Further, it has a very large number of new technology-based firms especially in electronics hardware, computer software and in biotechnology industries. India's aerospace industry has its origin in Bangalore with the establishment of three major institutions in that city, namely the NAL, the HAL and the ISRO. No other place in India has such a large density of aerospace-related institutions as Bangalore has. Although the Bangalore aerospace cluster is now more than 50 years old, over the last ten years or so it has evolved into a fairly sophisticated and clearly identifiable cluster. Three factors appear to have contributed to this change. First, is the increasing market for aircraft within the country thanks to the phenomenal growth in domestic air travel and the increasing success of India's space programme which has also increased with India emerging to have capability in designing and launching satellites using her own indigenously designed satellite launch vehicles. Second, is the launching of R\&D of India's first civilian aircraft, the HANSA and SARAS in 1991 and the establishment of the Antrix Corporation in 1992 for the promotion and commercial exploration of products and services from the Indian space programme. Third, is the growth of R\&D outsourcing by foreign aerospace companies and one does hear, with increasing frequency, of an increasing number of such outsourcing outfits being located in the country and most of them again happen to be in Bangalore. An indication of the growing importance of 
Bangalore's aerospace potential can be gauged from the fact that during a recently concluded Aero India 2009 air show - billed as the largest in South Asia - deals worth more than $\$ 1.2$ billion were signed between Indian and foreign aerospace firms. For all these reasons, the SSI of India's aeronautical industry has a clearly identifiable geographical dimension.

Regarding the SSI of India's aeronautical industry, I first sketch its historical evolution followed by a mapping of the contours of the sector in terms of the three building blocks: key actors and institutions, knowledge or technological domain and demand.

\subsection{Brief historical evolution of the sector}

The sector has a history of very nearly seven decades (Table 1).

Table 1 Historical evolution of the India's aeronautical industry

\begin{tabular}{ll}
\hline Year & Major institution/policy instrument \\
\hline 1940 & Hindustan Aircraft Company (first aircraft company) \\
1942 & $\begin{array}{l}\text { Formation of India Institute of Science and Council of Scientific and Industrial } \\
\text { Research (CSIR) }\end{array}$ \\
1948 & Aeronautical Society of India established \\
1958 & Establishment of Defence Research and Development Organization (DRDO) \\
1959 & NAL formed \\
1964 & HAL formed \\
1969 & ISRO formed \\
1972 & Space Commission and Department of Space formed \\
1991 & Society of Indian Aerospace Industries and Technologies (SIATI) formed \\
1992 & Antrix Corporation formed \\
2001 & Defence production opens to private players \\
2005 & Offset clause added to India's Defence Procurement Procedures (DPP). The clause was \\
& elaborated further in 2006 and 2008. \\
2006 & Defence Offset Facilitation Agency (DOFA) formed \\
2009 & Entry of Foreign aerospace manufacturers such as Boeing and Airbus. \\
2010 & National Civil Aircraft Development (NCAD) project launched \\
\hline
\end{tabular}

Source: Based on PWC and CII (2009)

An interesting aspect of the history is that India focused initially on the aeronautical part of the aerospace sector. In fact, the astronautic part came almost thirty years later. But it can be seen that later, government policy was focused much more on the astronautic than the aeronautical and it is in the former that India has managed to have some clear success.

It is seen that the very first entrant to India's fledgling aerospace industry was a domestic private sector company. The company traces its roots to the pioneering efforts of an industrialist with extraordinary vision, the late Seth Walchand Hirachand, who set up Hindustan Aircraft Limited at Bangalore in association with the erstwhile princely state of Mysore in 1940. The Government of India became a shareholder in March 1941 and took over the management in 1942. Later on in 1959, the NAL was established under the CSIR network. HAL came into existence on 1st October 1964. The merger of 
Hindustan Aircraft Limited with Aeronautics India Limited and Aircraft Manufacturing Depot, Kanpur formed the Company. HAL was to be become the major and in fact the only aircraft manufacturing company in the country as the industry was reserved exclusively for state-owned enterprises. The industry was deregulated in 1991 when private sector participation was allowed in for the first time. ${ }^{1}$

The astronautic part had its beginning in 1969. The major distinguishing aspect of the two sub sectors was that government had a much more articulated strategy for the development of the astronautic industry while it had virtually no policy or strategy for the aeronautical sector excepting to direct its activities almost exclusively to the defence needs. In the initial period and almost up to the new millennium, the country was much more preoccupied with creating institutions for both material production and indeed for knowledge generation as well. However, during the period since 2000, there is a radical shift in terms of first privatising the industry and then putting in place a number of instruments to stimulate domestic production of aerospace products. One can also see a transformation of a state-owned undertaking dominated industry focusing exclusively on defence production to one that is beginning to get populated with private domestic and even foreign companies. In fact, as one can see from Table 2, while the country has a regular and increasing public budget on astronautic, it hardly spends anything on aeronautical research targeted especially at the commercial sector.

Table 2 Trends in public budget devoted to astronautic and aeronautical research in India (Rs in millions at current prices)

\begin{tabular}{lccccc}
\hline & $\begin{array}{c}\text { Public } \\
\text { budget on } \\
\text { astronautic } \\
\text { research }\end{array}$ & $\begin{array}{c}\text { Public } \\
\text { budget on } \\
\text { aeronautical } \\
\text { research* }\end{array}$ & GDP & $\begin{array}{c}\text { Astronautic } \\
\text { research } \\
\text { share (\%) }\end{array}$ & $\begin{array}{c}\text { Aeronautic } \\
\text { research } \\
\text { share (\%) }\end{array}$ \\
\hline $1998-1999$ & 15,110 & & $16,160,820$ & 0.09 & \\
$1999-2000$ & 17,260 & & $17,865,260$ & 0.1 & \\
$2000-2001$ & 19,090 & & $19,250,170$ & 0.1 & \\
$2001-2002$ & 19,090 & $20,977,260$ & 0.09 & Negligible \\
$2002-2003$ & 21,640 & 945.2 & $22,614,150$ & 0.1 & Negligible \\
$2003-2004$ & 22,740 & $1,042.8$ & $25,381,700$ & 0.09 & Negligible \\
$2004-2005$ & 25,400 & $1,088.1$ & $28,777,010$ & 0.09 & Negligible \\
$2005-2006$ & 26,750 & $1,377.7$ & $36,924,850$ & 0.07 & Negligible \\
$2006-2007$ & 29,970 & $1,573.2$ & $42,936,720$ & 0.07 & \\
$2007-2008$ & 32,900 & & $49,864,260$ & 0.07 & \\
$2008-2009$ & 40,740 & & $55,826,230$ & 0.07 & \\
$2009-2010$ & 41,630 & & $65,502,710$ & 0.06 & \\
$2010-2011$ & 48,800 & & $78,779,470$ & 0.06 & \\
$2011-2012$ & 66,260 & & & & \\
\hline
\end{tabular}

Note: *These are proxied by the funds allocated to NAL at Bangalore.

Source: Government of India (various issues) and CAG (2008)

Finally, although India started its aeronautical activities (both research and manufacturing) almost three decades prior to another developing country, Brazil, she has been much less successful in this area as the country had no clearly articulated policy for 
the sector, while in the astronautic part, where the policy and instruments were more clearly articulated, one sees a fair amount of successes. I will elaborate on this in the subsequent sections.

\subsection{Mapping the SSI}

Based on my field visits and on the basis of secondary source material, I have been able to map out the SSI of the aerospace sector (see Figure 2). The sector consists of six different types of institutions. They deal with research, regulation, assembly of aircraft, three different tiers of component suppliers and higher education institutions that train aeronautical engineers. Majority of these institutions are located in the same geographic area, namely Bangalore that would have promoted greater interaction between these different agencies. However, as will been later, this is not the case. The level of interaction between the various agencies is somewhat weak because India did not have civilian aircraft manufacturing project of some significance. But this is to change with the recent launching of the NCAD project, which may actually promote the linkages between these agencies. The existing level of interaction was also dictated by security concerns as the main aircraft manufacturer was only engaged in the manufacture of aircraft for the defence.

Figure 2 The sectoral system of innovation of India's aeronautical industry (c2010)

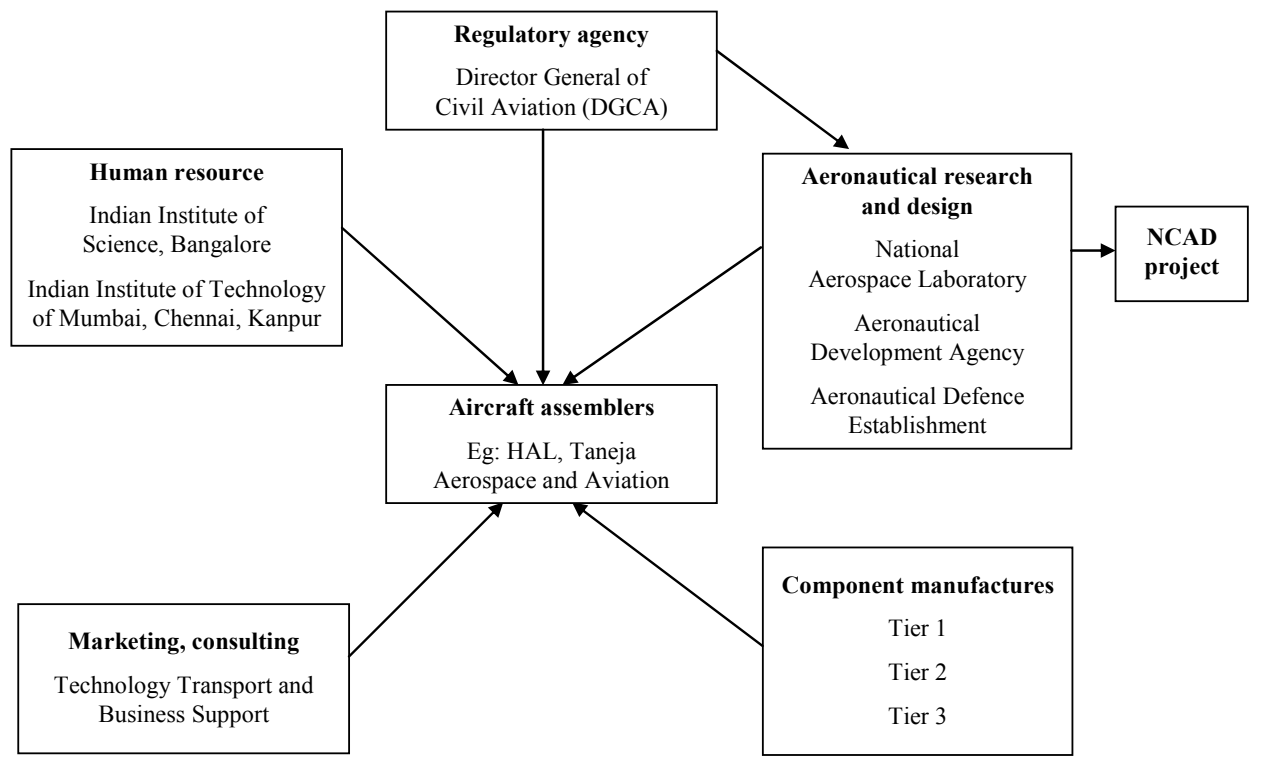

Source: Own compilation

In terms of the aerospace value chain, the SSI has design firms, component manufacturers and aircraft assembly firms. Within the component manufacturers, most of them are tier 3 suppliers (Figure 3). There are of course two assemblers, HAL being the, largest of them, although its capability is almost entirely oriented towards defence-related aircraft. 
Figure 3 Aeronautical value chain

\begin{tabular}{|c|c|c|c|c|c|}
\hline \multicolumn{3}{|c|}{ Manufacturing value chain } & \multicolumn{3}{|c|}{ Service value chain } \\
\hline Design & $\begin{array}{l}\text { Component } \\
\text { manufacturers }\end{array}$ & $\begin{array}{c}\text { Aircraft } \\
\text { assembly }\end{array}$ & $\begin{array}{c}\text { Leasing and } \\
\text { financing }\end{array}$ & $\begin{array}{l}\text { Sales and } \\
\text { distribution }\end{array}$ & MRO services \\
\hline $\begin{array}{c}\text { - Design infrastructure } \\
\text { And services } \\
\text { - CAD } \\
\text { - Prototyping } \\
\text { - Research } \\
\text { - Aerodynamics } \\
\text { - Engine \& fuel } \\
\text { - Communications } \\
\text { - Testing infrastructure } \\
\text { And services } \\
\text { - Wind tunnels and } \\
\text { model testing } \\
\text { - Engine and rocket } \\
\text { testing facility } \\
\text { - Flight testing } \\
\text { - Other engineering } \\
\text { services (IT) }\end{array}$ & $\begin{array}{l}\text { Tier-1 suppliers } \\
\text { - Power plant and } \\
\text { propulsion devices } \\
\text { - Avionics } \\
\text { - Landing gear assemt } \\
\text { - Wing assemblies } \\
\text { Tier-2 suppliers } \\
\text { - Electrical power } \\
\text { systems } \\
\text { - Flight controls (rudc } \\
\text { elevator, yoke) } \\
\text { - Hydraulic systems } \\
\text { - Escape systems } \\
\text { (ejection seats) } \\
\text { Tier-3 suppliers } \\
\text { - Castings and forgin } \\
\text { - Precision machined } \\
\text { parts: tubes } \\
\text { - Fasteners, bearings } \\
\text { - Standard } \\
\text { - Others (wiring harn }\end{array}$ & $\begin{array}{l}\text { - Superstructure } \\
\text { - Fuselage or body } \\
\text { - Empennage or tail } \\
\text { assembly } \\
\text { lies - Final assembly } \\
\text { er, } \\
\text {,s } \\
\text { ss) }\end{array}$ & $\begin{array}{l}\text { - Financing purch } \\
\text { - Leasing on a ne } \\
\text { service basis, or } \\
\text { and leaseback b }\end{array}$ & $\begin{array}{l}\text { - Dealerships } \\
\text { 1- Sales offices }\end{array}$ & $\begin{array}{l}\text { - Spare parts } \\
\text { - Service and } \\
\text { maintenance } \\
\text { - Regular } \\
\text { inspections } \\
\text { \& overhaul } \\
\text { - Systems } \\
\text { enhancement }\end{array}$ \\
\hline Source: & AT Kearney (20 & & & & \\
\hline
\end{tabular}

\subsection{Lead actors in the SSI}

In this section, I discuss some of the leading actors within the aerospace cluster in Bangalore. I divide the lead actors into two broad categories: first in terms of knowledge production and second in terms of material production actors in both the aeronautical and astronautic sectors. The focus is on the activities of these actors and the S\&T linkages that these actors have with other actors both in the cluster, elsewhere in India and even abroad. I first start with the research or knowledge base of the cluster followed by the manufacturing base although this division is by no means fool proof as some of the manufacturers themselves have their own in-house knowledge production centres (for instance in the case of the astronautic sector, ISRO does both knowledge and material production). The research base or knowledge production in aeronautics is led by the NAL (although the Indian Institute of Science, Bangalore has also a strong contribution to the research base with a steady supply of high quality human resource). With the recent launching of the NCAD project, the SSI of the sector is getting more clearly articulated.

\subsubsection{Actors dealing with knowledge production in aeronautics}

\subsubsection{National Aerospace Laboratory}

The NAL, Bangalore is a constituent laboratory under the CSIR of India. NAL is a high technology-oriented institution concentrating on advanced topics in the aerospace and related disciplines. Originally started as National Aeronautical Laboratory, it was renamed the NAL to reflect its major involvement in the Indian space programme, its multidisciplinary activities and global positioning. It is India's only civilian aerospace laboratory and has made significant contributions to a large number of aerospace programmes like aircraft (civil and military), space, engine development, defence and 
strategic programmes. NAL is an acknowledged centre of excellence in fields like composite structures, high speed wind tunnel testing, aircraft fatigue and aerospace acoustics, failure analysis and accident investigation. It has also successfully executed some innovative research projects in advanced topics like smart materials, parallel processing, advanced flow diagnostics, airport instrumentation, etc. NAL has been instrumental in the development of a light trainer (HANSA) and multi transport (SARAS) aircrafts. However, the lab does not have a good patent record during the five-year period 2002-2003 through 2006-2007 for which data are available. For instance during this five year period it has applied for 230 patents (21 in India and nine abroad). Of these 30 patents filed, 22 were filed from eight out of 456 completed projects during 2002-2007 and the balance eight patents pertained to the projects completed prior to April 2002. Therefore, during 2002-2007, only 2\% completed projects yielded any patents. Therefore, during 2002-2007, only $2 \%$ of the completed projects yielded any patents (Comptroller and Auditor General, 2008). It has, of course, a good publication record.

What is most worrying is its success in transferring and commercialising technologies developed by it. In a random sample of 146 projects that were analysed in depth, NAL could develop transferable technologies only in the case of 75 projects and out of this, only 25 (one third) was actually transferred to the end users. Of these 25 , only one could actually be commercialised. In other words, its knowledge level interactions within the cluster or elsewhere was very low and this is further substantiated by a more quantitative assessment of this issue.

Two of the major R\&D projects in the civilian aircraft space that the NAL has worked on in recent times are the development of two different types of aircraft; first a two-seater trainer aircraft called HANSA and the second a multi role light transport aircraft called SARAS. The development of these two aircraft has the potential of infusing some technological dynamism to the constantly evolving aerospace cluster in Bangalore.

The second and more complex one, SARAS is essentially a twin turboprop multi-role aircraft with air taxi and commuter services as its primary roles. The project started in 1991, had some interruptions in 1998 due to the sanctions imposed on India by the international community. ${ }^{2}$ The first prototype was field tested in 2003-2004 and the second one in 2007. But the technology is yet to be commercialised, as it still has to solve some technical issues with respect to the weight of the aircraft. NAL is at the moment initiated a new project to design a 70-90 seat regional transport aircraft (RTA) in a public-private partnership mode. Our inquiries reveal that currently it is the drawing board stage. It will be an aircraft, which could land, in an all-weather condition even in airfields, which do not have adequate ground infrastructure facilities like instrument landing system (ILS). The first test flight is to be done in 2015 and expects to commercialise the new technology by 2016.

I now propose to analyse NAL's interaction with other units in the cluster. There are two ways in which this interaction can be measured and presented. The first method depends entirely on qualitative data on the various types of interactions that the laboratory had with firms in the cluster in terms of transfer of technologies, provision of consultancy services, conduct of collaborative research projects, testing and analytical studies undertaken. The second method is to find out the ratio of the value of these transactions to the total budget of the lab and if this ratio is increasing over time, I assume that the lab's interaction with the cluster is increasing. Ideally speaking, I require both the 
methods to form an informed opinion on this important issue. However, since I do not have a comprehensive collection of qualitative data on external interactions, I conduct our analysis of this issue entirely in terms of the second method. For this, I rely on the numbers provided in CAG (2008). Based on this understanding I define two variants of a ratio called the interaction ratio (IR). The numerator of both the ratios is same: it is composed of fee received by NAL for:

1 collaborative projects

2 consultancy projects

3 testing and analytical assignments

4 transfer of technology.

This is aggregated and presented as total funds received through external interaction (Table 3). The denominator for IR1 is the total external cash flow (defined as the sum of funds received through external interaction and funds received through grants-in-aid and sponsored projects), while the denominator for IR2 is the total budget (grants from CSIR and total external cash flow).

Table 3 NAL's interaction within the SSI (Rs in millions)

\begin{tabular}{lccccc}
\hline & $\begin{array}{c}\text { Funds received through } \\
\text { external interaction }\end{array}$ & $\begin{array}{c}\text { Total external } \\
\text { cash flow }\end{array}$ & $\begin{array}{c}\text { Total } \\
\text { budget }\end{array}$ & IR1 & IR2 \\
\hline $2002-2003$ & 1.9 & 288 & 945.2 & 0.0066 & 0.0020 \\
$2003-2004$ & 1.1 & 334.5 & 1042.8 & 0.0033 & 0.0011 \\
$2004-2005$ & 1.8 & 277.4 & 1088.1 & 0.0065 & 0.0017 \\
$2005-2006$ & 3.1 & 305.80 & 1377.7 & 0.0101 & 0.0023 \\
$2006-2007$ & 3.4 & 336.90 & 1573.2 & 0.0101 & 0.0022 \\
\hline
\end{tabular}

Source: Derived from Table 1 of CAG $(2008$, p.7)

Although the funds received by NAL through external interaction has increased, as ratio of its total external cash flow and budget (IR1 and IR2) it is almost zero for all the years under consideration. This is entirely plausible as its R\&D projects in civilian aircraft technologies are yet to fructify.

\subsubsection{Actors dealing with material production}

These are divided into domestic and foreign manufacturers. Among the domestic manufacturers are the sate-owned enterprise, HAL and the private sector aircraft assembler, Taneja Aerospace. Among the two, HAL is the oldest and the largest having a range of capabilities and is likely to become one of the key aircraft manufacturers in the country. Given its paramount importance and given the availability of data, our discussion of domestic manufacturers is only in terms of HAL.

\subsubsection{Domestic manufacturers}

$H A L$ : is a major player in the global aviation arena. It is a defence state owned company and has built up comprehensive skills in design, manufacture and overhaul of fighters, trainers, helicopters, transport aircraft, engines, avionics and system equipment. Its 
product track record consists of 12 types of aircraft from in-house R\&D and 14 types by licence production inclusive of eight types of aero engines and over 1,000 items of aircraft system equipment (avionics, mechanical, electrical).

HAL has produced over 3,550 aircraft, 3,650 aero-engines and overhauled around 8750 aircraft and 28,400 engines besides manufacture/overhaul of related accessories and avionics.

HAL has 19 production divisions for manufacture and overhaul of aircraft, helicopters, engine and accessories. It has also nine $R \& D$ centres to give a thrust to R\&D.

HAL's major supplies/services are to Indian air force, Indian navy, Indian army, coast guard and border security force. Transport aircraft and helicopters have been supplied to airlines as well as state governments. The company has also achieved a foothold in export in more than 20 countries, having demonstrated its quality and price competitiveness. HAL is a major partner for the space vehicle programmes of the ISRO. It has also diversified into the fields of industrial and marine gas turbine business and real-time software business. HAL is now ranked 34th in the list of world's top 100 defence companies.

The company has made supplies to almost all the major aerospace companies in the world like Airbus, Boeing, IAI, IRKUT, Honeywell and Ruag, etc. In 1988, Airbus entered into an agreement with HAL to make doors for its A320. Primary interviews with HAL reveal that $50 \%$ of the forward doors for Airbus are manufactured by HAL. The company has also entered into an agreement with Boeing for the production of flaperons ${ }^{3}$ for use on Boeing's 777 series commercial jetliner.

All the production divisions of HAL have ISO 9001-2000 accreditation and 16 divisions have ISO-14001-2004 environment management system (EMS) certification. Six divisions have also implemented the aerospace sector quality management system requirements stated in AS 9100 standard and obtained certification. Four of these divisions have also obtained NADCAP certification (National Aerospace Defence Contractors Accreditation programme - USA) for special processes such as NDT, heat treatment, welding, etc.

In order to meet with the challenges in the 21 st Century, the company has redefined its mission as follows: "To become a globally competitive aerospace industry while working as an instrument for achieving self-reliance in design, manufacture and maintenance of aerospace equipment, Civil Transport Aircraft, helicopter and missiles and diversifying to related areas, managing the business on commercial lines in a climate of growing professional competence".

HAL has successfully designed and developed the advanced light helicopter, which is currently being operated by the defence services of India and private companies. The advanced light helicopter also has great export potential.

As a result of these expansions of its activities, HAL's total sales have increased, on an average, at a rate of $16 \%$ per annum (see Table 4). Its export intensity has doubled during the period under consideration while it has maintained its research intensity around $7.4 \%$ of its sales turn over. This is in fact one of the highest research intensities in the country. 
Table 4 Trends in HAL's domestic sales, exports, export intensity and research intensity

\begin{tabular}{ccccccc}
\hline & $\begin{array}{c}\text { Domestic } \\
\text { sales } \\
\text { (Rs in } \\
\text { millions) }\end{array}$ & $\begin{array}{c}\text { Export sales } \\
\text { (Rs in } \\
\text { millions) }\end{array}$ & $\begin{array}{c}\text { Total sales } \\
\text { (Rs in } \\
\text { millions) }\end{array}$ & $\begin{array}{c}\text { Export } \\
\text { intensity } \\
(\%)\end{array}$ & $\begin{array}{c}\text { R\&D } \\
\text { expenditure } \\
\text { (Rs in } \\
\text { millions) }\end{array}$ & $\begin{array}{c}\text { Research } \\
\text { intensity } \\
(\%)\end{array}$ \\
\hline $1994-1995$ & $13,529.5$ & 358.9 & $13,888.4$ & 2.65 & 961.2 & 6.92 \\
$1995-1996$ & $15,387.8$ & 281.3 & $15,669.1$ & 1.83 & $1,258.7$ & 8.03 \\
$1996-1997$ & $17,305.7$ & 396.4 & $17,702.1$ & 2.29 & 819.5 & 4.63 \\
$1997-1998$ & $18,288.8$ & 410.5 & $18,699.3$ & 2.24 & $1,298.3$ & 6.94 \\
$1998-1999$ & 20,037 & 440.3 & $20,477.3$ & 2.20 & $1,463.5$ & 7.15 \\
$1999-2000$ & $23,539.2$ & 469.6 & $24,008.8$ & 1.99 & $1,716.6$ & 7.15 \\
$2000-2001$ & $2,3879.4$ & 586.1 & $24,465.5$ & 2.45 & $2,040.9$ & 8.34 \\
$2001-2002$ & $27,079.6$ & 668.5 & $27,748.1$ & 2.47 & $2,037.2$ & 7.34 \\
$2002-2003$ & $30,165.3$ & $1,038.9$ & $31,204.2$ & 3.44 & $2,650.6$ & 8.49 \\
$2003-2004$ & $35,844.3$ & $2,153.5$ & $37,997.8$ & 6.01 & $3,138.1$ & 8.26 \\
$2004-2005$ & $43,837.5$ & $1,500.5$ & 45,338 & 3.42 & $3,066.3$ & 6.76 \\
$2005-2006$ & $51,553.1$ & $1,861.9$ & 53,415 & 3.61 & $4,335.8$ & 8.12 \\
$2006-2007$ & 75,131 & $2,705.1$ & $77,836.1$ & 3.60 & $6,377.9$ & 8.19 \\
$2007-2008$ & $82,842.5$ & $3,410.9$ & $86,253.4$ & 4.12 & $6,621.4$ & 7.68 \\
$2008-2009$ & 99,368 & $4,365.8$ & $103,733.8$ & 4.39 & $6,747.8$ & 6.50 \\
$2009-2010$ & $112,520.30$ & $2,046.70$ & $114,567.0$ & 1.82 & $8,321.20$ & 7.26 \\
\hline
\end{tabular}

Source: HAL (2010)

HAL is also one of the most profitable aerospace companies in the world (see Table 5).

Table 5 Profitability of HAL among World Aerospace Companies

\begin{tabular}{lcccccc}
\hline $\begin{array}{l}\text { Rank by } \\
\text { margin } \\
2009\end{array}$ & $\begin{array}{c}\text { Rankby } \\
\text { margin } \\
2008\end{array}$ & $\begin{array}{c}\text { Rankby } \\
\text { aerospace } \\
\text { sales }\end{array}$ & Company name & $\begin{array}{c}\text { Aerospace } \\
\text { sales } \\
(2009) \$ m\end{array}$ & $\begin{array}{c}\text { Operating } \\
\text { margin } \\
(\%)\end{array}$ & $\begin{array}{c}\text { Operating } \\
\text { margin } \\
(\%)\end{array}$ \\
\hline 1 & 1 & 69 & TransDigm Group & 762 & 44 & 42 \\
2 & 2 & 73 & FLIR Systems & 655 & 30 & 26 \\
3 & 4 & 32 & Precision Castparts & 2,991 & 27 & 23 \\
4 & 3 & 98 & Garmin & 246 & 27 & 25 \\
5 & 5 & 38 & HAL & 2,337 & 23 & 23 \\
6 & 15 & 99 & Martin-Baker & 235 & 23 & 15 \\
7 & 6 & 68 & Chemring & 786 & 20 & 21 \\
8 & 14 & 44 & Meggitt & 1,794 & 20 & 15 \\
9 & 7 & 25 & Rockwell Collins & 4,470 & 20 & 20 \\
10 & 97 & 96 & Hampson Industries & 264 & 19 & -1 \\
\hline
\end{tabular}

Source: Flight International (2010, p.40) 


\subsubsection{FDI and foreign partnerships in the SSI}

An interesting aspect of India's aerospace SSI is the proactive role of the government with respect to FDI in the aerospace sector and also an active encouragement given to forging partnerships between foreign and local enterprises leading to some transfer of technology and joint technology development. We first discuss two major instances of FDI into the sector followed by a discussion of the partnerships that are now increasingly forged between foreign and local enterprises.

\section{FDI in India's aerospace industry}

There are two major instances of FDI, of those by Airbus and by Boeing.

1 The Airbus Engineering Centre India (AECI): a 100\% Airbus-owned subsidiary is one of the most important foreign aircraft manufacturing enterprises in the Bangalore aerospace cluster. Specialising in high-tech aeronautical engineering, the India engineering centre works hand-in-hand with other Airbus Engineering offices around the world, as well as with the Indian aviation industry. As of December 2011, 260 people were working at the facility - including homegrown engineers and other employees - and this number is expected to grow over the next four years. As part of the AECI's activity, a simulated A380 flight management system is being developed in cooperation with Airbus engineers in Toulouse, France. This effort will help Airbus systems engineers to provide mature specifications for the suppliers of flight management systems (FMS) and also can be used in R\&D work on evolved FMS functions for new programmes such as the A350 XWB.

2 The Boeing: In 2005, Boeing entered a research partnership with the Indian Institute of Science (IISc) which focused on research in nanotechnologies, structural alloys, composites, smart materials and structures, process modelling and simulation, manufacturing technologies, prototyping through substructure fabrication and testing. The strategic alliance with the IISc - the first of its kind at Boeing in the area of materials science - is expected to spur aerospace innovation and contribute to the advancement of Boeing's aircraft design capabilities. In March 2009, Boeing opened its Boeing Research and Technology-India centre, which marks a major milestone for Boeing's aerospace research and technology activities in India. The centre will be the focal point for all Boeing technology activities in India, collaborating with Indian R\&D organisations, including government agencies and private sector R\&D providers, universities, and other companies. It will work with strategic research and technology partners to develop high-end technology, particularly in the areas of aero structures and avionics. The India centre is one of the three advanced centres, which Boeing has outside the USA.

\section{Partnerships between foreign and local enterprises}

According to AT Kearney (2010) a number of partnerships have been forged between foreign and Indian enterprises (see Table 6). Two of the leading Indian automobile manufacturers and of the leading private airline companies have established links with some of the leading foreign players. Given the fact that technology collaboration agreements are hard to come by in this industry, these partnerships are an effective way of securing the much needed technology inputs. In fact, it is generally felt that these 
partnerships can provide India with a conduit for emerging as a manufacturer of smaller aircrafts and helicopters in the very near future.

Table 6 Partnerships between Indian and foreign enterprises

\begin{tabular}{|c|c|c|c|}
\hline Company & $\begin{array}{l}\text { Alliance } \\
\text { partner }\end{array}$ & Segment & Nature of alliance \\
\hline \multirow[t]{3}{*}{ TATA } & Boeing & $\begin{array}{l}\text { Defense } \\
\text { aircraft } \\
\text { components }\end{array}$ & $\begin{array}{l}\text { - Signed memorandum of understanding (MOU), } \\
\text { February } 2008 \\
\text { - Initial orders of } \$ 500 \text { million } \\
\text { - Planned production in Nagpur SEZ }\end{array}$ \\
\hline & Sikorsky & $\begin{array}{l}\text { Chopper cabin } \\
\text { manufacturing }\end{array}$ & $\begin{array}{l}\text { - Signed MOU (February 2008) } \\
\text { - Tata Advanced Systems (TAS) to manufacture } \\
\text { S.92 helicopter cabins in India }\end{array}$ \\
\hline & $\begin{array}{l}\text { Piaggio } \\
\text { Aero }\end{array}$ & $\begin{array}{l}\text { Aircraft } \\
\text { manufacturing }\end{array}$ & $\begin{array}{l}\text { - Purchased } 33 \% \text { stake (August 2008) } \\
\text { - Tata to market turboprops in India } \\
\text { - Taj Air establishes service centre in India }\end{array}$ \\
\hline \multirow[t]{2}{*}{$\begin{array}{l}\text { Kingfisher } \\
\text { Airlines }\end{array}$} & Epic & $\begin{array}{l}\text { Aircraft } \\
\text { manufacturing }\end{array}$ & $\begin{array}{l}\text { - Purchased 50\% stake (December 2007) } \\
\text { - Company builds small business jets } \\
\text { - Plans to market aircraft in Middle East }\end{array}$ \\
\hline & $\begin{array}{l}\text { EADS } \\
\text { Socata }\end{array}$ & $\begin{array}{c}\text { Aircraft } \\
\text { manufacturing }\end{array}$ & $\begin{array}{l}\text { - Initiated discussions (June 2008) } \\
\text { - Company plans to co-develop business jets } \\
\text { - Planned investment of } \$ 200 \text { million }\end{array}$ \\
\hline \multirow[t]{2}{*}{ Mahindra } & Plexion & $\begin{array}{l}\text { Aerospace } \\
\text { design }\end{array}$ & $\begin{array}{l}\text { - Acquired } 88.41 \% \text { stake } \\
\text { - Company provides computer-aided engineering } \\
\text { services to the aerospace sector }\end{array}$ \\
\hline & $\begin{array}{l}\text { National } \\
\text { Aerospace } \\
\text { Laboratories } \\
\text { (India) }\end{array}$ & $\begin{array}{l}\text { Aircraft } \\
\text { manufacturing }\end{array}$ & $\begin{array}{l}\text { - Initiated running contract to develop jointly a } \\
\text { five-seat aircraft }\end{array}$ \\
\hline
\end{tabular}

Source: Adapted from Figure 3 of AT Kearney (2010)

\subsubsection{Software firms in the cluster}

Apart from this hardware-related entities in the cluster, the SSI of India's aerospace industry is also very well known for a number of software firms which have become important players in the software requirements of some of the international aerospace industry. Mention may be made of two of them, namely WIPRO and Quest (see Box).

Based on the qualitative and quantitative data on the major entities in the SSI, the main difference between the aeronautical and astronautic components of the sector is the important fact that the sector is now increasingly getting organised around civilian projects especially in the case of the aeronautical sector. Further the aeronautical cluster is increasingly getting integrated with the international aerospace industry. The astronautic sector, on the contrary, focuses much more on forging linkages within the 
country even though here too I could detect change in the form of a number of emerging international linkages.

Box Software firms active in the Bangalore aerospace cluster

WIPRO

- Agreement to work jointly on commercial aerospace projects with Britain's BAE Systems

- Entered into an agreement with Boeing to develop wireless and other network technologies for aerospace-related applications (PPP)

- Partnered with Lockheed Martin to create demonstration centres showing new capabilities for linking multiple control centres, aircraft and vehicles

- Wipro became the largest hydraulics company in India and the second-largest globally after an acquisition in Sweden. It is assessing the possibility of creating new designs for smart landing gears and brakes.

Quest

- QuEST supports its aerospace customers on global programmes related to aero structures, engines, accessories, actuation systems, aircraft interiors and ground support equipment. It also specialises in complete end-to-end solutions for the aerospace industry right from design and analysis to manufacturing.

- QuEST has been selected as EADS E2S preferred supplier for engineering services, manufacturing capabilities, ability to offer offset fulfilment and risk sharing partnerships. The firm recently entered into a JV to launch India's first independent processing facility for aerospace manufacturing and has setup a special economic zone (SEZ) in Belgium

Source: PWC and CII (2009)

In the aeronautical sector some of the important linkages observed are:

a Airbus has been assessing ways to use India for component manufacturing and R\&D. It had announced that India would be one of the key centres for design and development of their new A350 aircraft. Airbus Engineering Centre India is the company's high-tech aircraft component manufacturing facility in Bangalore. The facility works on the development of tools to design the aircraft, software for analysing the stress and strain on airplanes and structural analysis of the aircraft, among other things.

b Snecma, a leading global aerospace company, established its R\&D centre in India in 2002. This centre is engaged in carrying out studies and developing engine components, aircraft equipment and onboard software.

c Several foreign and private players that have entered the Indian R\&D sphere followed the public private partnership (PPP) model for sharing technology/knowledge and commercialising aerospace manufacturing. Prominent partnerships include:

d In 2008, Boeing had entered into agreements with Indian Institute of Science, Wipro and HCL to develop wireless and other network technologies for aerospace-related applications. 
e In 2007, Mahindra and Mahindra had signed an agreement for the design and development of a new general aviation aircraft with The NAL, CSIR and the Government of India. This is the first public private JV in the aircraft design sector in India.

\subsubsection{Auto parts firms diversifying to aerospace industry}

Finally, important finding of the study is that a number of auto parts manufacturers have actually entered the aerospace industry: Indian automotive companies are also well positioned to leverage their strengths towards aerospace. The auto component sector is growing at approximately $20 \%$ per year and many global OEMs and tier 1 companies have started sourcing components from India, due to the high quality standards followed by Indian manufacturers. For instance, India has the largest number Deming Award winning companies outside Japan (11) in the auto component sphere and proven practices such as 5S, TPM, TQM and JIT are used by companies. The companies are also conversant with the multiple automotive standards followed in different parts of the globe. Several players are planning to enter the aircraft components production. Most are primarily becoming involved with precision engineering, machining, aircraft lighting, manufacture of tyres and transmission components. For example, Tata Automobile Ltd (TAL) entered into an agreement with Boeing to manufacture structural components for their 787 Dreamliner airplane programme.

The SSI of the sector is therefore constantly evolving with the entry of new actors. Numbers of new actors are entering the sector and the linkages that the domestic actors are forging with those abroad are increasing as well.

\section{Knowledge and technology domain}

According to Malerba (2004) any sector is characterised by a specific knowledge base, technologies and inputs. Knowledge plays a central role in innovation and affects the types of learning and capabilities of firms. In a dynamic way, the focus on knowledge and the technological domain places at the centre of the analysis the issue of sectoral boundaries, which usually are not fixed, but change over time. Knowledge is highly idiosyncratic at the firm level, does not diffuse automatically and freely among firms, and has to be absorbed by firms through their differential abilities accumulated over time.

Regarding the aerospace sector in India, in the knowledge domain the case of astronautics has been fairly well established and researched. As seen earlier, the country has through the ISRO, built up considerable innovation capabilities in four important areas of space research such as:

a earth observations and remote sensing (CARTO series)

b satellite communications and navigation (INSAT series)

c space science and environment (Chandarayan 1 and 2)

d launch vehicles (PSLV, GSLV). 
Among these four areas, the one were India has built considerable technological competence are in the areas of remote sensing and in the design and manufacture of satellite launch vehicles and in satellites itself. We discuss these two areas, albeit briefly.

With reference to remote sensing, Satheesh (2009) has shown that although considerable competencies have been built in this area of technology its actual diffusion for especially urban land planning has been limited due to a variety of factors including certain regulatory policies of the government itself like for instance the map policy that existed in the country prior to 2005 which discouraged the use of maps with high resolutions. This has since changed. An important innovation in this area has been the development ISRO launched the beta version of its web-based 3-D satellite imagery tool, Bhuvan, on August 12, 2009. Bhuvan will offer superior imagery of Indian locations compared to other Virtual Globe software (like Google Earth and Wiki Mapia) with spatial resolutions ranging from $10 \mathrm{~m}$ to $100 \mathrm{~m}$. For the present, Bhuvan is available only for India specific locations although it is capable of offering images of the entire earth. It is supposed to be having a number of positive characteristics compared to its immediate competitor, Google Earth. But given the large number of technical glitches that the software suffer from its actual diffusion rate has been limited. However, Bhuvan represents a new kind of capability in the case of ISRO in terms of combining both astronautic and software capabilities.

Two other areas in which ISRO has built capabilities are in the design of satellite launch vehicles and in the satellites itself. In India, the launch vehicles development programme began in the early 1970s. The first experimental satellite launch vehicle (SLV-3) was developed in 1980. An augmented version of this, ASLV, was launched successfully in 1992. ISRO has made tremendous strides in launch vehicle technology to achieve self-reliance in satellite launch vehicle programme with the operationalisation of polar satellite launch vehicle (PSLV) and geosynchronous satellite launch vehicle $(\mathrm{GSLV})^{4}$. In terms of satellites, ISRO has developed two major space craft systems, the Indian national satellite system (INSAT) series for communication, television broadcasting and meteorological services which is a geostationary satellite, and Indian remote sensing satellites (IRS) system for resources monitoring and management which is earth observation satellites. Between 1975 and 2011 it has launched a total of 60 satellites accounting for about a percent of the world satellite launches. China has of course, a better record in terms of number of launches.

Of the two types of launch vehicles, India has a better success rate wrt PSLVs (almost 80\% during 1993-2009) compared to its GSLV programme (of the four operational flights, two were a failure and the other one was a partial failure). An indicator for measuring PSLVs reliability is the fact that it has launched eight satellites for various customers from abroad. An interesting aspect of ISRO's knowledge development has been the instutionalised process for learning from past launch failures. In fact, as I shall see later on that this is in sharp contrast with what I observe in the cause of India's aeronautical technology development where no such procedures existed.

We now turn our attention to the issue of knowledge development in the case of India's aeronautical industry. Although considerable expertise had been developed in defence aircrafts of various vintages, the sector turned its attention to civilian aircraft technologies only towards the end of the 1980s. These initiatives are discussed in detail below in terms of two different technology development exercises.

It was seen earlier that NAL had developed two civilian aircraft, one a two-seater trainer and the second one a 14-seater multipurpose turbo prop one. In this section, I 
discuss whether through these R\&D projects NAL had actually fostered a cluster of aerospace units manufacturing a range of components and other parts required for these two projects. In discussing these two cases I supplement our primary data source with the data obtained from one of the recent Comptroller and Auditor General Reports (CAG, 2008) on scientific establishments in the country. Both the cases are first discussed separately and then some common threads are deduced from these two related cases.

\section{The trainer aircraft (HANSA) case}

The project was initiated in 1988 at a total estimated cost of Rs 5 million and was expected to be completed in about two to three years. Market research by NAL showed that considerable demand existed for this type of small aircraft to be used primarily for training and for remote sensing purposes. The project suffered serious time and cost overruns - the project could be completed only in 1998 at a final cost of Rs 55 million implying a time overrun of around seven years a whopping cost overrun of $1,000 \%$. While time and cost overruns are standard for especially high tech R\&D projects, what was disquieting was that the aircraft was designed with $100 \%$ foreign components and no effort was made by NAL to source even a small proportion of the total components required from domestic sources. Consequently, the project had very little linkage effects within the SSI of India's aerospace industry or elsewhere in the country. NAL was also unable to transfer the HANSA technology to the only other private sector aeronautical manufacturing company namely TAAL. However, TAAL refused to participate as a risk-sharing partner but chose to work as a contractor. As a result NAL decided to undertake the certification, production and marketing of the aircraft by itself. The initial demand for HANSA was restricted to ten aircraft demanded by the Directorate General of Civil Aviation (DGCA) for eventual supply to the flying clubs around the country. NAL incurred a total expenditure of Rs 4.34 million per aircraft as against the initial target of Rs 0.05 million per craft. Of the ten, NAL was able to supply the DGCA with only eight up to the end of June 2007. Nothing much is known about the remaining two as to whether it has been supplied or not. Of the eight, two met with accidents, but according to the CAG $(2008$, p.25, para 1.8.1.3) report NAL did not have any documents on investigations on these accidents done by either they themselves or the DGCA and so, could not even create an institutionalised mechanism for learning from these mistakes. Also, it was very clear that not much demand existed for these crafts beyond the original eight.

From the case, the following general points emerge. NAL does not appear to have done a systematic project preparation in terms of first assessing the market for this technology, second, keeping a tab on both the time and cost of the project and in developing an indigenous vendor network and finally in instituting a framework within the lab to learn from its failures as these kind of failures are usually a fact of life in complex technologies such aerospace. Success lies in learning from these failures and then taking appropriate actions for further improvements.

\section{The multi transport (SARAS) case}

This was one of the most ambitious projects that the NAL had undertaken. The idea, as noted before, was to develop a multi-purpose Light Transport Aircraft (9 to 14 seats). Under the project, two prototypes were to be fabricated to obtain DGCA certification. 
The competent financial authority (CFA) approved a budget of Rs. 1,314 million for the project. Of this, Rs. 653.1 (50\%) million was to be contributed by Technology Development Board, Rs. 90 million (7\%) by HAL and balance Rs. 571 million (43\%) by CSIR. While Prototype-I was targeted to fly in January 2001, the Prototype-II was expected to fly in December 2001. As against the target of January 2001, the Prototype-I flew in May 2004, i.e., after a delay of more than three years. Prototype-II undertook its first flight in April 2007, after a delay of more than five years. Due to the above time overrun, the cost of the project increased by Rs. 225.30 million, i.e., a cost overrun of about $17 \%$. Right through the beginning the two prototypes developed had a problem wrt its weight (in specific terms it was overweight). This meant that its certification by DGCA has been delayed and from press reports it is leant that the certification may be available only towards the end of 2011 as a third and lighter prototype has to be made for that purpose. In the meantime, it is also understood that the Indian airforce has expressed an interest to order 15 SARAS aircraft. The actual manufacturing of these aircraft will be by HAL. It is not immediately clear whether NAL has sourced the components and sub systems used in the aircraft were sourced from within the SSI of India's aerospace industry or from vendors elsewhere in the country. The only system that was purchased from indigenous sources was the auto pilot unit. However, we had seen earlier that TAAL has manufactured the entire airframe of the aircraft (excluding the wings which are manufactured by HAL) including tooling, parts and assembly. In this way, the SARAS project did have linkages, albeit of a very limited nature, with other units in the SSI of India's aerospace industry. Once the commercial manufacturing starts, these linkages are bound to increase manifold.

\subsection{The new RTA project}

In view of the expected increase in the demand for smaller aircraft with a seating capacity of 70 to 90 seats that can connect tier 2 and 3 cities with the major hubs in the larger metros, the government has decided to develop a commercial aircraft of that capacity in the next three years or so. This is known as the NCAD project. A high power committee (HPC) has been established and the project is to be implemented in a public-private sector partnership mode with NAL as the lead actor. The HPC is in the process of developing a more clearly articulated SSI. NAL officials say that they plan to design the aircraft with the Indian market in mind, adding that existing turboprops (like ATRs for instance) do not meet those requirements. These include higher fuel efficiency, short landing and take-off capability, and the ability to transport cargo.

This will give the aircraft $25 \%$ lower acquisition costs, and operating costs and $50 \%$ lower maintenance costs than existing turboprop regional aircraft, says NAL.

The 70-seater version of it will have a range of $1,100 \mathrm{~nm}(2,000 \mathrm{~km})$, and require a take-off field length and landing field length of $900 \mathrm{~m}(2,950 \mathrm{ft})$. But at least three reasons can make this project a very risky one. First, is the international market for RTA in which there exist considerable oligopolistic competition by established players. Unless the yet to be developed aircraft is going to be cost competitive, it is unlikely to be received well by the private sector airliners. Second, NAL is yet to perfect the technology for the 14-seater multi-transport aircraft which, inter alia, is hampered by the lack of availability of requisite knowledge for weight optimisation. Third, the country lacks sufficient number of aerospace engineers. Success of the NCAD project crucially depends on a resolution of all the three. 


\subsection{Human resource for technology generation}

An important prerequisite for the generation of knowledge development in this sector is the availability of highly trained human resource. In fact, two of the lead actors in the aeronautical sector have had severe difficulties with respect to both securing and retaining highly skilled engineers. For instance according to the CAG (2008), although the sanctioned strength of the lab was 460 scientists and engineers, it had at any point of time vacancies to the tune of $26 \%$ to $17 \%$. In fact, despite its best efforts in recruiting, the lab failed to find suitable candidates for the various posts indicating thereby lack of availability of good quality aerospace engineers. A similar story exists in the case of both HAL and ISRO. This is despite the fact that four of the original Indian Institutes of Technology (namely at Chennai, Mumbai, Kanpur and Kharagpur) have a four-year undergraduate programme in aerospace engineering and the Indian Institute of Science at Bangalore has even a master's and doctoral programmes in aerospace engineering. Notwithstanding these factors, the number of aeronautical engineers graduating from the country has not shown much increase $1996^{5}$ (see Table 7).

Table 7 Outturn of aerospace engineers from various technical universities in India (in numbers)

\begin{tabular}{lccc}
\hline & Aeronautical & $\begin{array}{c}\text { Total number of engineering graduates } \\
\text { in all branches of engineering }\end{array}$ & Share (\%) \\
\hline 1991 & 58 & 44,724 & 0.13 \\
1992 & 75 & 44,141 & 0.17 \\
1996 & 102 & 75,650 & 0.13 \\
1997 & 113 & 73,936 & 0.15 \\
1998 & 117 & 75,210 & 0.16 \\
1999 & 90 & 72,247 & 0.12 \\
2000 & 90 & 74,323 & 0.12 \\
2001 & 132 & 94,639 & 0.14 \\
2002 & 127 & 101,914 & 0.12 \\
\hline
\end{tabular}

Source: Institute of Applied Manpower Research (2008)

In response to this perceived shortage, the ISRO has started the Indian Institute of Space Science and Technology at Trivandrum, Kerala during the academic year 2007-2008 and the institute has the present capacity to outturn 40 undergraduates in three disciplines of aerospace engineering, avionics and physical sciences although for the present all the graduating students are expected to be absorbed within the ISRO itself. In fact, the supply of sufficient quantity of human resource of the right quality is an important requirement for successful knowledge generation. A recent Parliamentary Committee (Lok Sabha Secretariat, 2007) had noted that there is a severe shortage of design engineers in the field of aerospace engineering within the country and that is likely to affect many of the R\&D projects in the area. If India wants to be a serious player in the aeronautical industry, this crucial human resource supply has to be addressed. 


\subsection{Demand}

It is fairly well known in the literature that demand plays an important and crucial role in stimulating innovations in high technology industries.

In view of India's high economic growth the demand for air travel has increased significantly. The demand emanates from two types of markets, first from commercial airliners and second from corporate customers who require smaller business jets. According to Directorate General of Civil Aviation (2011), the scheduled airlines have 419 and the non-scheduled operators have 360 aircraft as on December 31, 2010. The scheduled domestic passenger traffic has been growing at a rate of over $9 \%$ over the period 1991-2010 (see Table 8).

Table 8 Trends in the growth of civil aviation in India, 1991-2010

\begin{tabular}{lcc}
\hline & Number of passengers carried (million numbers) & Growth rate (\%) \\
\hline 1991 & 10.72 & -1.33 \\
1992 & 11.13 & 3.82 \\
1993 & 9.44 & -15.15 \\
1994 & 11.52 & 22.00 \\
1995 & 14.26 & 23.81 \\
1996 & 13.39 & -6.07 \\
1997 & 16.04 & 19.75 \\
1998 & 16.52 & 3.00 \\
1999 & 16.01 & -3.12 \\
2000 & 17.30 & 8.09 \\
2001 & 16.86 & -2.52 \\
2002 & 17.63 & 4.57 \\
2003 & 19.46 & 10.33 \\
2004 & 23.93 & 23.02 \\
2005 & 27.88 & 16.48 \\
2006 & 40.29 & 44.51 \\
2007 & 51.90 & 28.81 \\
2008 & 49.88 & -3.89 \\
2009 & 43.84 & -12.11 \\
2010 & 51.53 & 18.66 \\
\hline
\end{tabular}

Source: DGCA

This market is bound to increase further with the modernisation of all the major airports and the opening up of a number of smaller airports in second tier cities. The demand is, therefore, particularly strong for smaller aircraft between second tier cities and major metropolitan hubs. In other words, it is forecast that the commercial aircraft market will grow to absorb about $\$ 100$ million worth of small and medium sized jets. Regarding the second market, namely the one for business jets Firestone Management Group, a private jet advisory, says there are 136 private jets registered in India with 43 jets added in the last three years (2008-2010 period). With the number of high net worth individuals increasing the demand for business jets is likely to pick up even further. 
A further impetus for demand may come from the Defence Procurement Policy (DPP). Although the DPP was first announced in 2002, an offset clause was attached to it in 2005. The clause was elaborated further in 2006 and 2008. It stipulates a minimum $30 \%$ plough back of foreign outflows from defence procurement into the Indian defence industry for all contracts above Rs 3 billion. The policy allows foreign vendors to choose their Indian offset partner, private or public. PWC-CII (2009) estimates that the combined offsets could translate into an opportunity of between USD 40 to 50 billion for the Indian market over the next 20 years $^{6}$. For example, the purchase of 126 medium multi-role combat aircrafts by the Indian Air Force will result in a potential offset opportunity in excess of USD 5 billion. The most notable change in DPP 2011 is the expansion of scope of offset policy guidelines to include civil aerospace within the ambit of eligible products and services for the discharge of offset obligations. In short, these policies may create an opportunity for Indian manufacturers to enter the high tech arena of aerospace manufacturing with its stringent requirements for safety, quality control and precision. We will examine this proposition, quantitatively, in the next section on performance.

\section{Performance of the aeronautical SSI}

In the previous section, we have mapped out the contours of the SSI of India's aerospace industry and then focused our attention on some of the lead players in the cluster. We found that there was fair amount of knowledge flows within the various actors and increasingly between these actors and foreign firms, customers and suppliers. Both the aeronautical and astronautic sectors have built up a fair amount of domestic technological capability in designing, manufacturing and selling aerospace products not only in India but even abroad. We basically discuss inter temporal performance of this sector in terms of a number of standard indicators.

\subsection{Inter-temporal comparison}

An important finding of the study is that the firms have, hitherto, been serving the export markets and the linkages that they have been having are more with other larger aircraft manufacturers outside the country. The main direct indicator of this link is the tremendous growth in exports, especially since the late 1990s. Exports have been growing at an average annual rate of $116 \%$ (in nominal terms) during the period, 1996-2009 (see Figure 4). However, imports too are on the increase, but the trade balance has started decreasing with some fluctuations. An interesting fact is that aerospace, probably is the only manufactured product in which the level of exports from India is at the moment (in 2009) even higher than that from China. ${ }^{7}$

Our analysis shows that almost the entire quantity that is exported is composed of parts of aircrafts. ${ }^{8}$ It is seen that the country is largely an exporter of aeronautical rather than astronautic products. This is because between the two, there is relatively speaking, a larger domestic market for the latter in view of the ongoing and increasing space programmes of the ISRO. So it is not incorrect to conclude that in the case of aeronautic component of the aerospace industry the most dominant linkage that you find in the cluster is between domestic component and smaller aircraft manufacturers with large aircraft manufacturers abroad. In the case of the astronautic component the linkages are between domestic manufacturers and their main consumer, which is the ISRO. The link 
between ISRO and their suppliers is actually forged through a commercial subsidiary of ISRO namely the Antrix Corporation.

Figure 4 Exports and trade balance of aeronautical products from India, 1996-2010 (in millions of US \$) (see online version for colours)

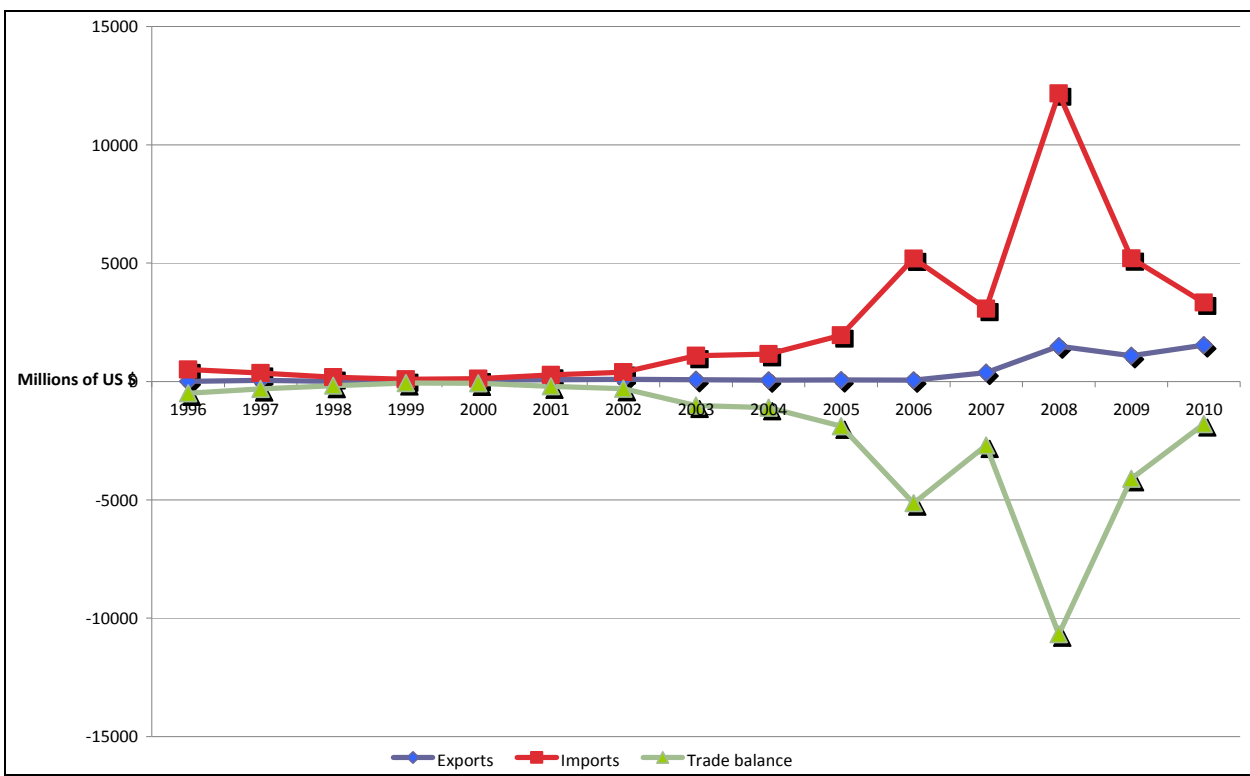

Source: Compiled from UN COMTRADE

Figure 5 Relationship between imports of aeronautical equipments and exports of aeronautical parts, 1996-2010 (see online version for colours)

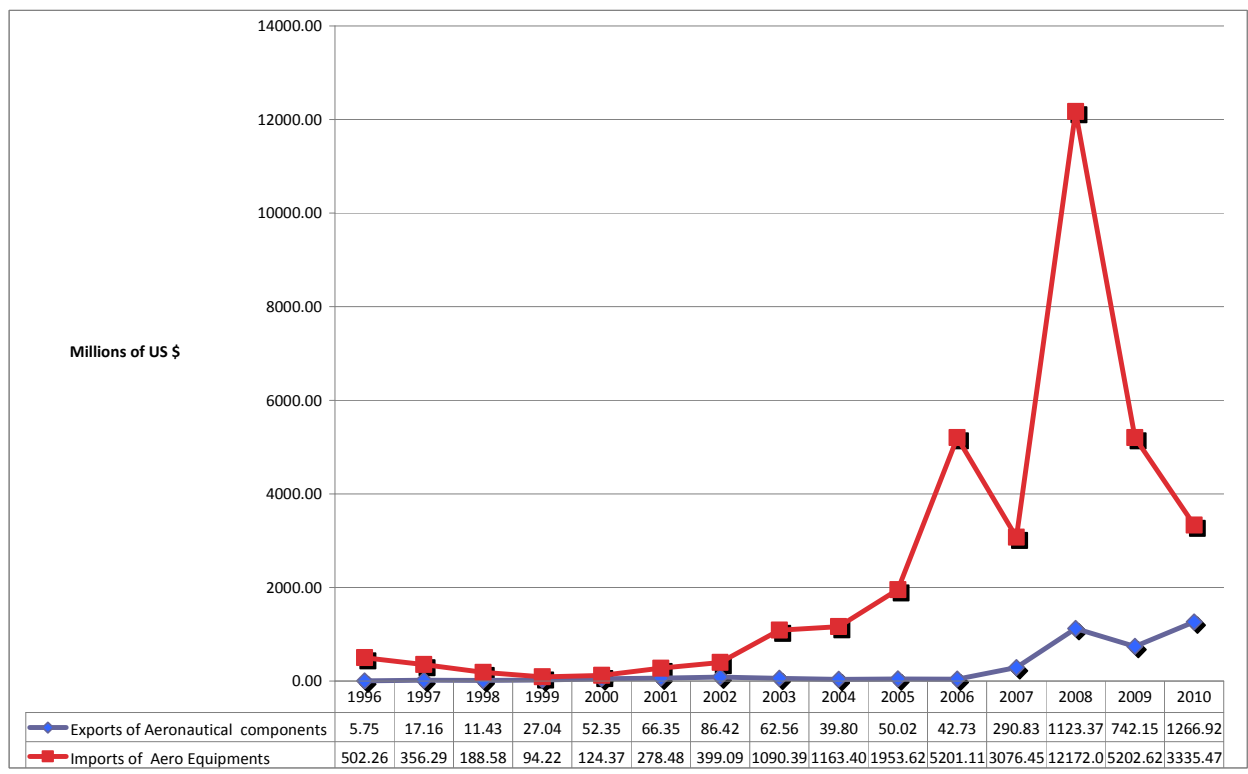

Source: Computed from UN COMTRADE 
The government recently announced the new policy for capital acquisitions in which the minimum requirement is of $30 \%$ offsets in all acquisitions where the purchase cost exceeds Rs 3 billion. Nearly $80 \%$ of all offsets are in the area of aerospace. As a result of this offset policy increasingly equipment suppliers to India are sourcing some portion of their components from India. So the increased exports of essential aeronautical parts from India are actually a result of this offset policy. In order to check this, I have plotted the export of aeronautical parts against import of aeronautical equipments. Given that the level of exports and imports vary considerably, we have transformed the two series into logarithmic values and this is plotted against each other over time (Figure 5). The figure shows that the two series are correlated with each, with zero-order correlation coefficient between the two working out to about $(+) 0.73$. In fact the lower correlation between the two is a function of the degree of operationalisation of the offset policy. A very clearly articulated offset policy existed only since 2005 .

\section{Conclusions}

India's aeronautical industry is slowly but steadily evolving from its defence focus to civilian ones. This can be seen in both in its aeronautical and astronautic sectors. In the aeronautical sector, India is in the process of developing civilian aircraft which is capable of serving the regional routes - something which Brazil has accomplished several decades ago and that too with great success. Further, the country has become a source of parts, components and software solutions to the International aerospace industry. The SSI of India's aeronautical industry has been particularly dynamic from this point of view having been very successful in attracting two of the leading aerospace companies in the world, namely Airbus and Boeing to establish both research and manufacturing facilities in the sector. The new policy on special economic zones too have been very helpful in furthering the geographic spread of the SSI of India's aerospace industry to the periphery of the city of Bangalore thus relieving itself of the infrastructural bottlenecks that the city has now become rather notorious for.

Although India has a very clearly articulated policy and targets for the astronautic sector she does not have a clear policy for developing the aeronautical sector. The government hopes to turn this constraint into an advantage through the offset clause, mentioned in the DPP. The effective implementation of such an offset policy can facilitate the absorption and indigenisation of foreign aeronautic technologies that accrue to the country by way of offset deals. In doing this, the government wishes to emulate the success of Brazil. Discussions with industry and an engagement with the relevant literature (Behera, 2009) shows that the government by fine tuning the offset policy can use public technology procurement as a policy instrument through which it can place the industry to a sure flight path to success. But the government seems to be too much preoccupied by the domestic aviation industry rather than the aeronautical industry as such. Further, the government is also targeting the MRO sector. Another area where concerted action is required is both in the quantity and quality of aerospace engineers although some efforts in this direction are already visible. Finally, although India does not have a proven civilian aircraft technology, the sectoral system of production and innovation is increasingly getting articulated. 


\section{Acknowledgements}

Earlier versions of this paper have been presented at a seminar at UQAM, Montreal, Institute of Public Enterprise, Hyderabad, and at Globelics 2010 at the University of Malaya. The authors would like to thank Jorge Niosi and other participants at these seminars for comments and suggestions. The author would also like to thank V.S. Sreekanth for research assistance. None of them are responsible for any of the errors or shortcomings that may still remain in the paper.

\section{References}

AT Kearney (2010) 'India aerospace: poised for takeoff, emerging markets are prime growth targets for the aerospace industry', available at http://www.atkearney.at/content/misc/wrapper. $\mathrm{php} / \mathrm{id} / 50238 /$ area/aerospace/name/pdf_india_aerospace_1258990786f088.pdf (accessed on 27 April 2011).

Baskaran, A. (2005) 'From science to commerce: the evolution of space development policy and technology accumulation in India', Technology in Society, Vol. 27, No. 2, pp.155-179.

Behera, L.K. (2009) 'India's defence offset policy', Strategic Analysis, Vol. 33, No. 2, pp.242-253.

Comptroller and Auditor General of India (CAG) (2008) 'Performance audit on the National Aerospace Laboratory, Bangalore', Report No. PA 2 of 2008 (Scientific Departments).

Directorate General of Civil Aviation (2011), Aircraft Type Statistics, available at http://dgca.nic.in/reports/mar-ind.htm (accessed on 15 June 2012).

Flight International (2010) Years of Living Dangerously, Top 100 Special Report, 14-20 September, Flight International.

Government of India (various issues) Expenditure Budget, Vol. 2, Department of Space, available at http://indiabudget.nic.in/ (accessed on 7 March 2010).

Hindustan Aeronautics Limited (HAL) (2009) 'Annual report 2008-09', available at $\mathrm{http}: / / w w w . h a l-i n d i a . c o m /$ financials.asp (accessed on 5 March 2010).

Institute of Applied Manpower Research (2008) Manpower Profile India Yearbook 2008, Institute of Applied Manpower Research, New Delhi.

Kasturirangan, K. (2004) 'Indian space programme', Acta Astronautica, June, Vol. 54, Nos. 11-12, pp.841-844.

Lok Sabha Secretariat (2007) 'In-depth study and critical review of Hindustan Aeronautics Limited (HAL)', Standing Committee on Defence (2006-07), 14th Lok Sabha.

Malerba, F. (2004) Sectoral Systems of Innovation: Concepts, Issues and Analyses of Six Major Sectors in Europe, Cambridge University Press, Cambridge.

Murthi, K.R.S., Bhaskaranarayana, A. and Madhusudana, H.N. (2010) 'New developments in Indian space policies and programmes - the next five years', Acta Astronautica, Vol. 66, Nos. 3-4, pp.333-340.

OECD (2007) Space Economy at a Glance, OECD, Paris.

PricewaterhouseCoopers (PWC) and Confederation of Indian Industry (CII) (2009) Changing Dynamics, India's Aerospace Industry, Confederation of Indian Industry, New Delhi.

Rajan, Y (1988) 'Benefits from space technology: a view from a developing country', Space Policy, Vol. 4, No. 3, pp.221-228.

Sankar, U. (2007) The Economics of India's Space Programme, An Exploratory Analysis, Oxford University Press, Delhi.

Satheesh, K.G. (2009) 'Diffusion of public sector innovation: the case of remote sensing technology in India', Unpublished MPhil dissertation, Jawaharlal Nehru University, New Delhi. 


\section{Notes}

1 The first aircraft manufacturing company in the private sector, Taneja Aerospace and Aviation Ltd was established at Bangalore in 1991.

2 According to NAL sources, technological and procurement problems - arising out of US sanctions - have adversely affected the development of SARAS and raised the cost of its development although this view was contested by the CAG (2008) in its auditing of NAL's R\&D projects.

3 The 777 flaperons are a highly complex composite assembly that is instrumental in controlling the airplane's manoeuvrability in flight.

4 PSLV weighing about 300 tons at lift off has the capability to put 1,500 kg satellite in polar sun-synchronous orbit. GSLV 2,200 kg satellites into geo-stationary orbit.

5 We are constrained to report data only up to 2002 as this is the latest year for which such data are available. Not having up to data on the number of engineers has been a real problem for India.

6 The detailed exercises underlying these estimates are not easily available. Governmental estimates, on the contrary, place the figure at around USD 30 billion.

7 This is because in most manufactured products Chinese exports is almost 30 to 50 times higher than that from India's.

8 We have used the HS 1996 classification system for extracting the data on exports from the database, UN Comtrade. The following three types of parts

a aircraft propellers, rotors and parts thereof (880310)

b aircraft under-carriages and parts thereof (880320)

c aircraft parts nes (880330) accounts for the largest share of exports from India. 